\title{
Specimen Collections from Abraham Gesner's Geological Survey of New Brunswick (1838 to 1842)
}

\author{
Randall F. Miller ${ }^{1^{*}}$, Diane N. BuhaY ${ }^{2}$ And Michelle Hébert ${ }^{1}$ \\ 1. Steinhammer Palaeontology Laboratory, Natural Science Department, New Brunswick Museum, Saint John, \\ New Brunswick E2K 1E5, Canada \\ 2. University of New Brunswick, Saint John, New Brunswick E2L 4L5, Canada \\ ${ }^{\star}$ Corresponding author $<$ randall.miller@nbm-mnb.ca $>$
}

Date received: 20 March 2012 g Date accepted: 26 April 2012

\begin{abstract}
Abraham Gesner (1797-1864), the first government-appointed geologist in a British colony, developed a collection of rocks, minerals and fossils organized for scientific study that was more than simply a collector's curiosity cabinet. While his public museum was meant to show a variety of specimens representing the geological sciences, his New Brunswick collection was built largely for reference and documentation to support the geological survey of the Province that he conducted from 1838 to 1842 . The collection of Gesner's specimens at the New Brunswick Museum can be matched to the localities that he visited and described in his five reports, published from 1839 to 1843. Gesner's collection of New Brunswick specimens likely represents the second oldest government geological survey collection in the British Empire.
\end{abstract}

\section{RÉSUMÉ}

Abraham Gesner (1797-1864), premier géologue nommé par un gouvernement dans une colonie britannique, a constitué une collection de roches, de minéraux et de fossiles cataloguée aux fins d'études scientifiques : bien plus qu'une simple chambre des merveilles. Ouvert au public, son musée avait pour but d'exposer une variété de spécimens représentatifs des sciences géologiques. Quant à sa collection de spécimens du Nouveau Brunswick, elle a principalement été amassée aux fins de référence et de documentation pour appuyer l'étude géologique de la province qu'il avait menée de 1838 à 1842. La collection de Gesner exposée au musée du Nouveau Brunswick contient des spécimensrecueillisdansleslocalitésqu'ilavisitées etdécritesdanscinqrapportsparusentre 1839et 1843.Lacollection de spécimens du Nouveau Brunswick de Gesner occupe vraisemblablement le deuxième rang des plus anciennes collections de l'Empire britannique amassées à la suite d'une étude géologique commandée par un gouvernement.

[Traduit par la redaction]

\section{INTRODUCTION}

"Geology of New Brunswick - It has been believed by many that Geology is a science of limited usefulness, and not calculated to excite much, if any interest, beyond the extraordinary facts which it develops with regard to the remains of animals and plants, now found in some of the hardest rocks. But if there ever was a time when mankind derived no benefit from this branch of Natural History, that time has passed away, and the labours of the Geologist have become of incalculable importance. Last year the House of Assembly placed a small sum at the disposal of the Lieutenant Governor, for the purpose of commencing a Geological Survey of the Province, and His Excellency Sir John Harvey, with his usual desire to promote the welfare of the country, employed Dr. Gesner to carry the intended object into effect."

(New Brunswick Courier - 9 February 1839) 
Abraham Gesner (1797-1864) is perhaps best known for his work to develop a process for the distillation of kerosene (Beaton 1955; Brice 2002) and for the museum he opened to the public on 5 April 1842 in Saint John, New Brunswick (Fig. 1). "Gesner's Museum", which displayed part of his collection of a reported 4000 specimens (Miller and Buhay 2007), survives today as one of Canada's oldest geological collections, and includes specimens acquired from Canada, the United States of America and Europe. In this paper, we focus on Abraham Gesner's geological survey of New Brunswick and collections he made during that work. Gesner is recognized as the first government geologist appointed in a British colony (Russell 1976; Zeller 1987; Cumming 1988). His appointment was only three years after the establishment of the Geological Survey of Great Britain in 1835 (Zeller 1987) and four years before the founding of the Geological Survey of Canada in 1842 (Zaslow 1975).

When Gesner opened his museum to the public in 1842 it was one of the first of its kind in what was to become Canada (Miller and Buhay 2007). Teather (2005, p. 53) observed that many early natural history museums in Canada "developed on the edge of the proper museum world"; they were different from institutional museums and more about spectacle than of serious educational or scientific purpose. In this category she included "Gesner's Museum" as an example from the Maritimes. Miller and Buhay (2007) argued that Gesner did develop a serious museum, organized for scientific study and more similar to institutional museums like the Geological Survey of Canada collection than to a collector's curiosity cabinet. His collection likely had its start in the 1820 s and initially comprised rock and mineral specimens collected near his home in Parrsboro, Nova Scotia. Gesner trained as a physician, but he was more than an amateur geologist. While studying medicine in London, England (ca. 1825-1827), he was introduced to a wider understanding of geology (Barkhouse 1980).

Gesner continued his interest in geology when he returned to Nova Scotia, and in 1835 he met with Ebenezer Emmons (1799-1863) and Albert Hopkins (1807-1872) from Williams College, Massachusetts, as they led the first North American college geological field trip (FalconLang 2009). They traveled to eastern Canada where Gesner met them at points along the Nova Scotia coast, and he was with them for their visit to Joggins. In 1836 Gesner published Remarks on the Geology and Mineralogy of Nova Scotia (Gesner 1836). Specimens in the "Gesner's Museum" collection relate to his geological exploration of Nova Scotia. By 1840 he had been elected a Fellow of The Geological Society of London (W. Cawthorne, Geological Society Library, personal communication 2006). Gesner later guided Sir Charles Lyell (1797-1875) on his first trip to Joggins in 1842 (Lyell 1845; Calder 2006). Gesner's collection at the New Brunswick Museum includes what are probably some of the earliest specimens gathered from that locality.

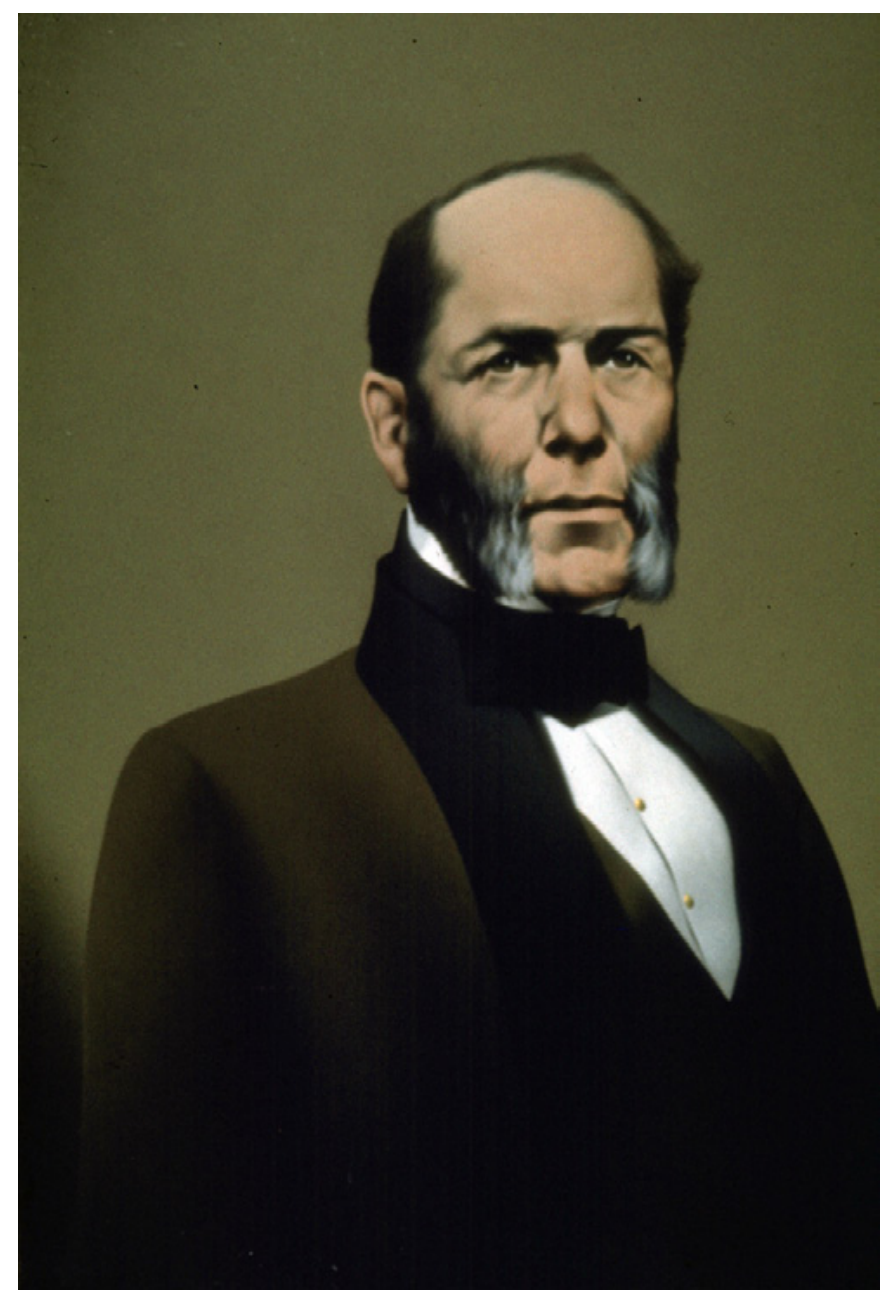

Fig. 1. Abraham Gesner (1797-1864). Painting, oil on canvas, by Canadian artist Lawren Phillips Harris, 1960. Commissioned from the artist (New Brunswick Museum 1979.120).

Gesner's collection of New Brunswick specimens, in both his public museum (referred to as "Gesner's Museum") and specimens not arranged for public display, represents the earliest government geological survey collection in Canada. While his public museum was meant to show a variety of specimens from the geological sciences, his collection overall was built for reference and documentation. Gesner's collection ultimately became part of the Natural History Society of New Brunswick holdings in 1890 (Miller and Buhay 2007). In his 1890 "President's Annual Address", George Matthew (1837-1923) reviewed the Society's recent acquisition of the Mechanics' Institute collection, noting the included Gesner specimens as a highlight of the new material. Matthew stated "In the Gesner museum is the collection of rocks, minerals and fossils made by Dr. Gesner when employed on the Geological Survey of New Brunswick. These are of historical interest, and with them 
in hand the reader of Dr. Gesner's reports will be able to understand what he meant by the terms serpentine, and grauwacke, trap and other obsolete terms of the geological literature" (Matthew 1890, p. 34).

\section{BECOMING PROVINCIAL GEOLOGIST}

While still living in Nova Scotia, in 1837 Gesner worked in New Brunswick for a private company, the Salmon River Coal Company, assessing potential coal reserves. In September 1837, he launched his strategy to establish a Provincial Geological Survey. Gesner lobbied hard, outlining the need for such a survey in seven open letters published in the New Brunswick Courier newspaper between 16 September and 18 November 1837. The letters, addressed to His Excellency Major General Sir John Harvey (1778-1852), the Lieutenant Governor, argued the benefits of a geological survey to the prosperity of the Province. In the letters, Gesner described the geology of New Brunswick as he knew it, beginning with the coal age rocks of southeastern New Brunswick (New Brunswick Courier - 16 September 1837). His next two letters described the geology along the road from the Nova Scotia border to Saint John (New Brunswick Courier - 23 September 1837 and 30 September 1837). In his fourth letter (New Brunswick Courier - 7 October 1837) Gesner expanded his observations of the geology along several river valleys in the south and southeast, and the lower St. John River. Letter five (New Brunswick Courier -21 October 1837) was more of a general overview of the geology of the Province. In the sixth letter (New Brunswick Courier - 4 November 1837), Gesner provided comments on his survey of coal mines and also on a trip from Saint John to Grand Lake, and on to Richibucto on the Northumberland Strait. Gesner finished his letters to the Lieutenant Governor (New Brunswick Courier - 18 November 1837) writing more of a travelogue than strictly geological observations. The letters suggest that, prior to the start of his provincial survey work, Gesner's travels in New Brunswick were largely limited to the area east of the St. John River, north as far as Fredericton and east to Richibucto. The letters are not clear about whether Gesner collected specimens on his travels but, given that he had been acquiring specimens for at least a decade in Nova Scotia, he may well have collected specimens during his 1837 rambles.

Sir John Harvey ultimately supported Gesner's idea for a provincial survey. So, on 22 January 1838, the Lieutenant Governor sent a message to the New Brunswick House of Assembly to encourage establishment of a geological survey (Anonymous 1838, p. 83) and on 9 February, 1838 , a sum of not more than $£ 200$ was dispersed to allow the Lieutenant Governor to employ a competent person for the job (Anonymous 1838, p. 134). Gesner received instruction to begin the survey on 17 April 1838 (Gesner
1839), and moved to Saint John to take up his new duties. Not everyone was impressed with Gesner's suitability. In June of 1838, a letter in a Saint John newspaper claimed that many of Gesner's observations were simply noting mineral deposits already well-known and that a survey should be conducted by "persons of standing in society, of acknowledged acquirements, and holding public office; such as the Professors of Natural Philosophy of King's College" and that "It cannot be conceived, how Surveys conducted in any other manner can be useful to the Province; and they will only lead to the unprofitable and prodigal waste of the public money." (Weekly Chronicle - 1 June 1838).

A small specimen collection at the New Brunswick Museum was reportedly presented by Gesner to George Stilman Hill in the 1840s. Hill was a member of the Legislative Assembly from 1831 to 1846. Perhaps Gesner sought the favour of other politicians in his bid to conduct and continue a survey.

\section{GESNER'S GEOLOGICAL SURVEY}

Gesner published five reports on the geology of New Brunswick (Gesner 1839, 1840, 1841, 1842a, 1843) before the government decided to terminate his services. On $18 \mathrm{March}$ 1842, the Legislative Assembly voted against approving a sum of money "for the purpose of providing for the expenses of Doctor A. Gesner in 1842, in continuing the Geological Survey of the Province", thus ending the work (Anonymous 1842 , p. 179). Gesner's geological reports provide details of his travels through the Province and his observations on the geology. The reports led to his production of the first geological map of New Brunswick, which was reported to have been first in the possession of the Mechanics' Institute and then the Natural History Society of New Brunswick (Matthew 1897). Although the original has not been located, Geoffrey Stead (1872-1943), a civil engineer and member of the Natural History Society, redrew a black and white version for Matthew (1897) to reproduce in his paper (Fig. 2), in which he reviewed Gesner's scientific work, with a particular focus on Gesner's reports of fossils. Matthew also stated that the geological map included work from Gesner's first three reports and that he [Matthew] had filled in the geology from the fourth report, north to the Shippagan region.

Gesner's five reports are laid out as travels along coastlines or rivers, as transects across the province, or studies conducted in various communities (Fig. 3). There is also much in the reports that has little to do with geology, but provides interesting information about early nineteenth-century New Brunswick. Gesner visited mines in operation, although there were few, and made comments on the potential for economic development of geological resources. He published his reports in a timely fashion, 


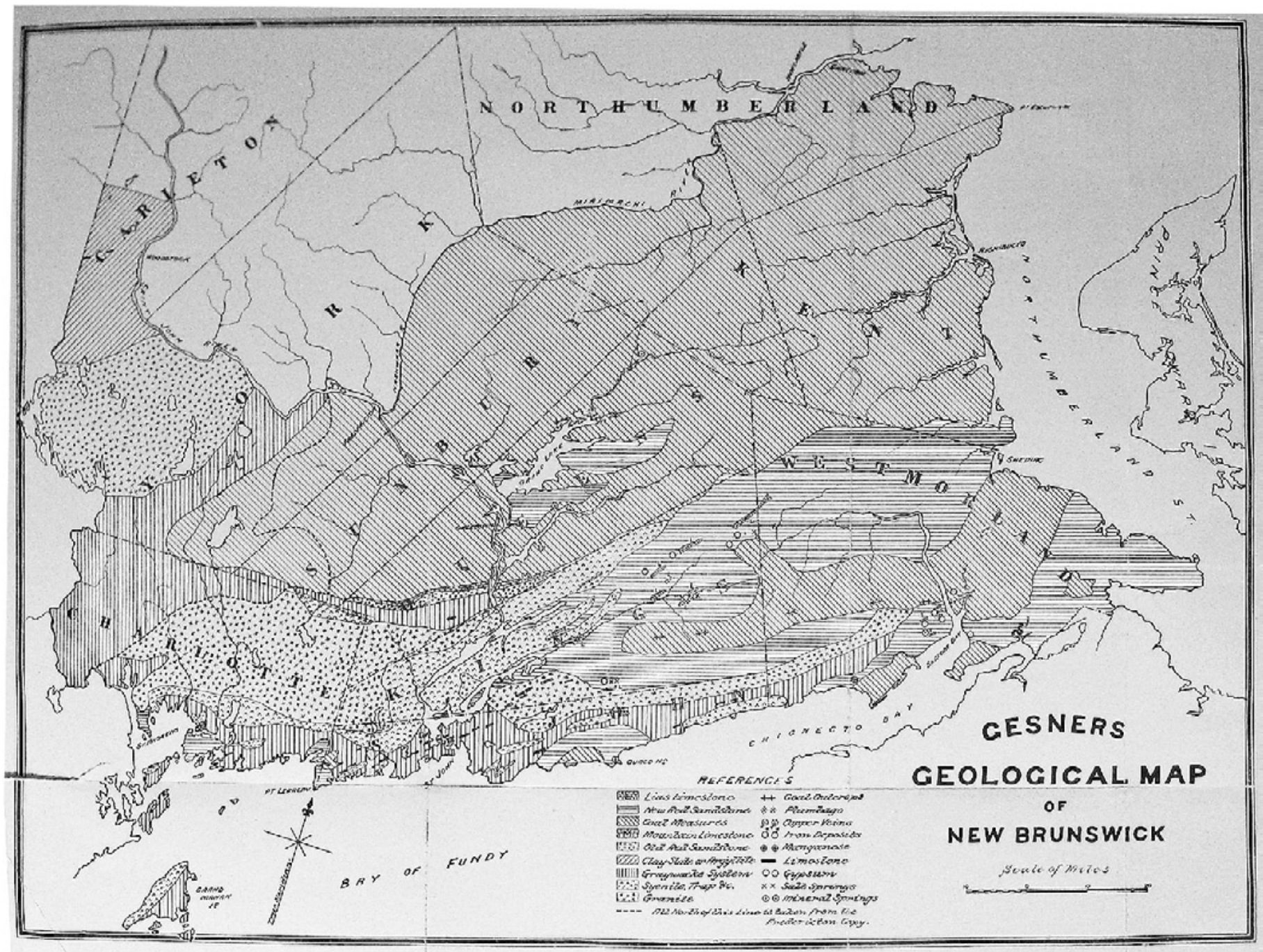

Fig 2. Abraham Gesner's geological map reproduced by Geoffrey Stead and included as a fold-out map by Matthew (1897). The original coverage by Gesner was extended north by George Matthew to include geological information published by Gesner in his fourth report (Gesner 1842).

produced the year following his survey work. In general his travels took him from west to east along the south of New Brunswick, and farther north in later years. In 1838 Gesner began his survey in Charlotte County, visiting St. Andrews, St. Stephen, islands in Passamaquoddy Bay and then along the coastline to Saint John. He also followed a line from the mouth of the Magaguadavic River to Oromocto (Gesner 1839).

The 1839 survey work (Gesner 1840) took Gesner from Saint John, east along the coast past Quaco (Fig. 4) and Martins Head to Hopewell, and inland to Hampton and Sussex. He then travelled to Shediac, Sackville, and Dorchester to examine the Westmorland Coal Fields. His travels in 1840 took Gesner back to complete his survey of St. John County near Gondola Point, Mispec, Black River,
Emersons Creek and Hammond River. He again visited the Westmorland Coal Field after which he traveled to Smiths Creek and along the Kennebecasis River. He examined what he called the New Red Sandstone of Westmorland and Kings Counties, and worked near Kingston, Springfield and Wickham, then on to Washademoak Lake and Grand Lake (Gesner 1841).

In 1841 Gesner moved inland towards Oromocto, Fredericton, Schoodic and Cheputnecticook, Pokiok, Woodstock, Northampton, Southampton, Queensbury, Douglas, Nashwak, and the "Great Coal Field" of Kent and Northumberland Counties. He explored along the Tedish River, and then moved north along the Northumberland Strait coast to Cocagne, Richibucto, Kouchibouguac, Chatham, Newcastle and Miramichi (Gesner 1842a). There 

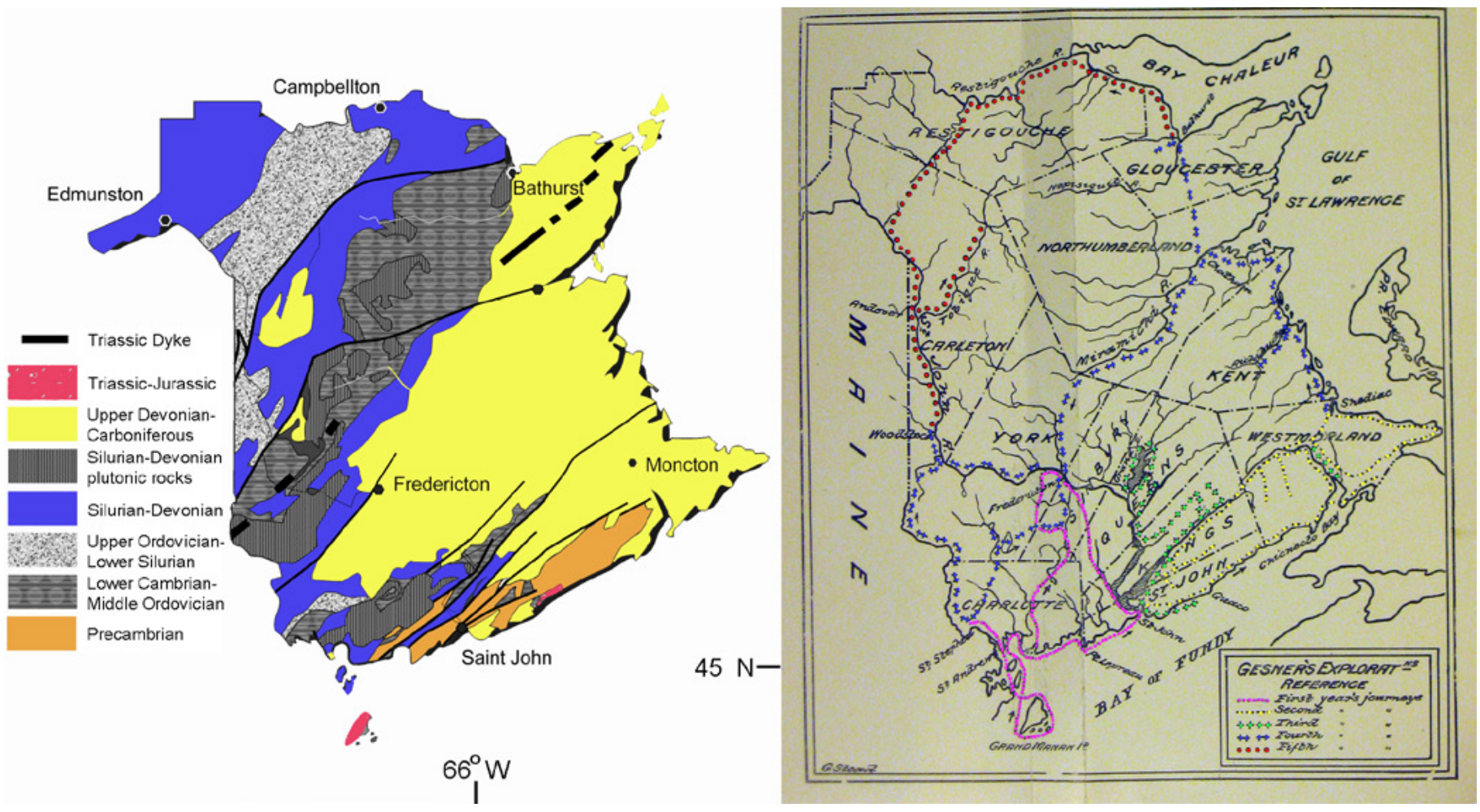

Fig 3. General geology map of New Brunswick (left). Map of Abraham Gesner's geological survey travels (right) compiled by Geoffrey Stead for the Bulletin of the Natural History Society of New Brunswick (Matthew 1897). Colour added to designate travel routes related to each report.
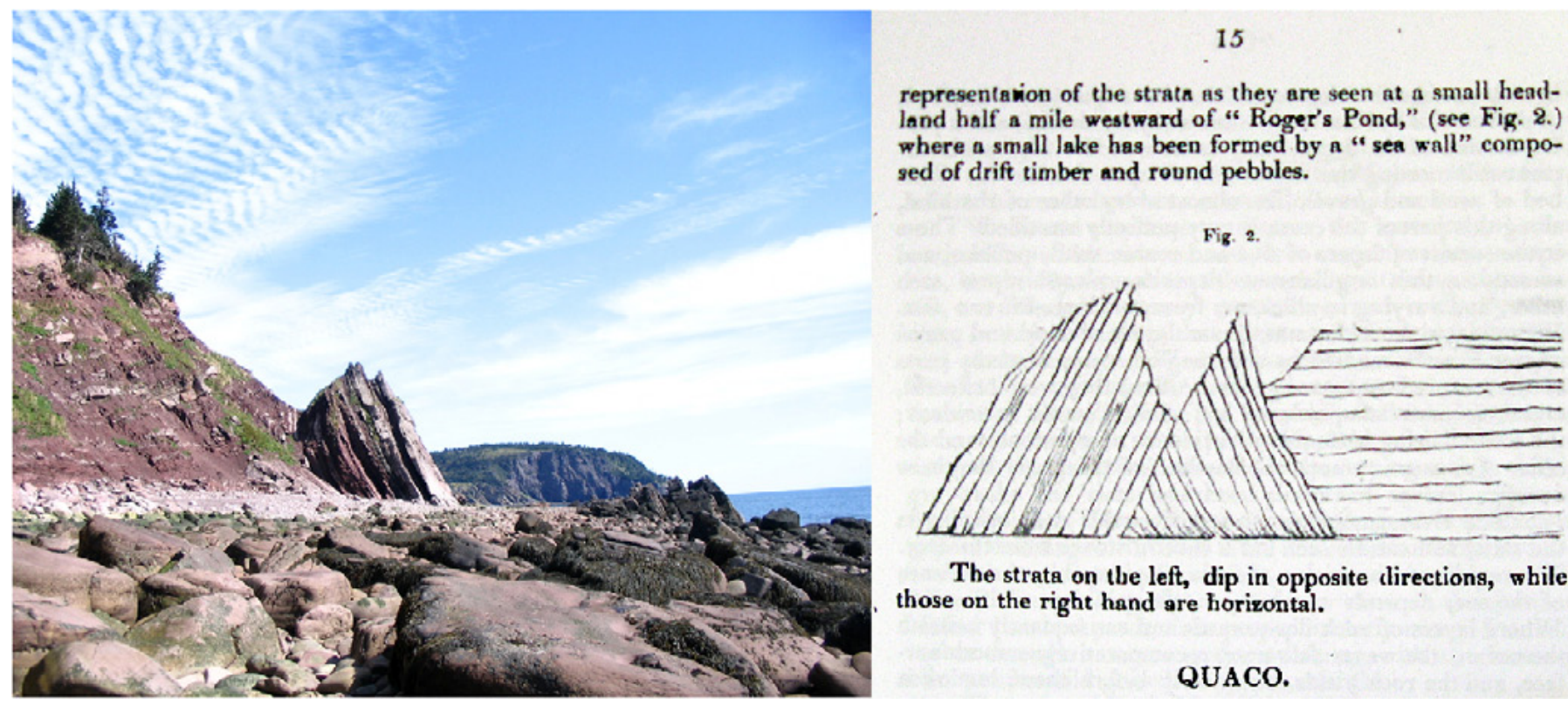
sed of drift timber and round pebbles.

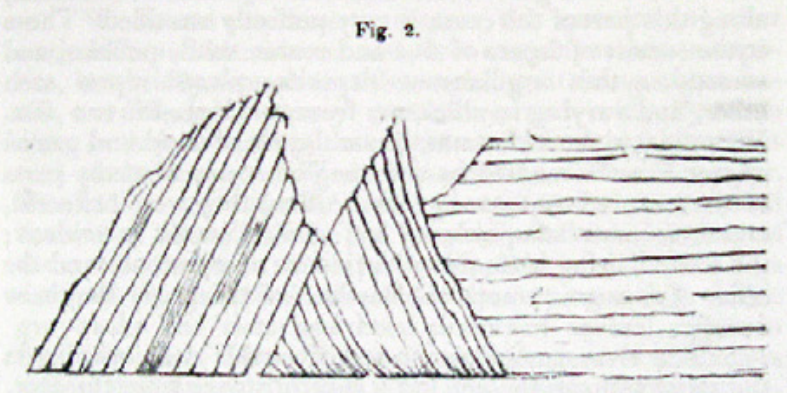

The strata on the left, dip in opposite directions, while those on the right hand are horizontal.

\section{QUACO.}

Fig. 4 At left, a 2008 photograph showing a slump block of the Upper Carboniferous Tynemouth Creek Formation, near Quaco, west of Giffin Pond. Rogers Head can be seen in the distance. At right, Abraham Gesner's illustration of the same outcrop (Gesner 1840, p. 15, fig. 2). 
had been some dismay at Gesner's lack of northern field work in previous years. The Miramichi Gleaner published a critical commentary that read, "While upon the subject of a Mineralogical Survey - we cannot refrain from noticing that the inhabitants of this County were the first to Petition the Legislature to grant a sum of money for a Mineralogical and Geological Survey of the Province, commencing with this county. It shared the fate of very many other petitions of practical utility from this quarter - it was thrown out. The following year, if our memory serves us, Dr. Gesner was appointed Provincial Geologist; he has visited several Counties of the Province, published two annual reports, and this is to be his last year of service; and although this is considered, nay known, to be the most valuable section in Mineral Wealth, he has not yet made his appearance in this quarter. We should very much like to be made acquainted with the reason for this apparently designed neglect" (Miramichi Gleaner - 21 July 1840).

Gesner's last report on a geological survey of the province (Gesner 1843) included a topographical account of the public lands and districts he explored. In his final year Gesner explored the north of the Province, including the northern stretches of the St. John River near Grand Falls and farther north along the Restigouche River, and the Bay of Chaleur shore to Dalhousie and southeast to Bathurst. Gesner had opened his museum to the public in April 1842, before his last season of field work. Specimens collected during 1842 were not published in his museum catalogue (Gesner 1842b), but were later listed by George Matthew in an unpublished document "Appendix to the Catalogue of Gesner's Museum 1842-1843" (New Brunswick Museum Archives - Natural History Society Fonds S 128A, F 133). This was likely prepared after the Natural History Society acquired Gesner's collection in 1890.

\section{GESNER'S GEOLOGICAL SURVEY COLLECTION}

The present New Brunswick Museum, incorporated in 1929, traces its origin to "Gesner's Museum". The New Brunswick Museum holdings contain specimens collected by Gesner, including those displayed in his museum, collections of the Mechanics' Institute in Saint John from their museum established in 1843, and the collections of the Natural History Society of New Brunswick founded in 1862. All three of these nineteenth-century collections began as separate entities, but by 1890 they had all been brought together into the collections of the Natural History Society (Matthew 1913). While this helped ensure their survival, it has created problems tracing the origin of some specimens. Collections were integrated, sometimes re-labeled and occasionally combined as special collections. Determining the origin of specimens is often problematic, especially since the same types of rocks, minerals and fossils were collected repeatedly from the same sites. The Natural History Society of New Brunswick also purchased collections from places such as Ward's Natural Science and Footes Minerals, or received donations from other institutions such as the Geological Survey of Canada. Specimens from the "Gesner's Museum" display collection have been recognized based on a specific label Gesner used to mark specimens (Fig. 5A). His entire collection was possibly more than twice the size of that put on public display (Miller and Buhay 2007). His general collection was not labelled in the same manner as the public museum specimens. Although perhaps impossible to confirm, we believe many of the Natural History Society of New Brunswick rock and mineral specimens were originally part of Gesner's collection. Twenty-five years of re-organization of the New Brunswick Museum geology collection now allow us to speculate on the nature of Gesner's original collection. Clues such as particular labels (Fig. 5B, C) are now attributed to Gesner's collection, and all of the suspected Gesner New Brunswick specimens come from localities on routes of his provincial survey (Fig. 3).

Although hundreds of specimens in the New Brunswick Museum were likely part of Gesner's collection, we have confidently identified 164 New Brunswick specimens from localities across the province as Gesner's. With the exception of a few specimens he credited to other collectors, we believe that most were gathered by Gesner or his colleagues during the 1838 to 1842 surveys, though some may have been acquired during his 1837 travels. The only original specimen data is found in the published museum catalogue (Gesner 1842b), an unpublished "Appendix to the Catalogue of Gesner's Museum 1842-1843" prepared by G.F. Matthew (New Brunswick Museum Archives - Natural History Society Fonds S 128A, F 133) or, in a few instances, labels affixed to specimens (Fig. 5B). In the museum catalogue (Gesner 1842b), the "Minerals of New-Brunswick" list includes 71 specimens, although other minerals from New Brunswick are found under other headings. Minerals were collected from localities that include Grand Manan, Saint John, Washademoak, Miramichi, St. Stephen, Fredericton, Beaver Harbour, Richibucto, Woodstock, Shediac, Bathurst and Campobello. Plant fossils were collected from North Joggins (Rockport), Grindstone Island, Bathurst, Salmon River, Grand Lake, Saint John, Miramichi and Quaco, while invertebrate fossils came from Digdeguash, Ocnabog Lake, Restigouche, Dalhousie, St. Andrews and Grand Lake. Also among Gesner's specimens are rocks from Grand Manan, Saint John, Meductic, Nerepis, St. Martins, Campobello, Tobique and Bathurst. A review of Gesner's New Brunswick collection has allowed a reasonable match of most specimens (Fig. 6A-S) to entries in Gesner's five reports (Table 1).

Not all of the "Gesner's Museum" catalogue and Appendix records are represented by specimens at the New Brunswick Museum. Gesner listed 322 New Brunswick specimens in his museum and appendix lists, more than 

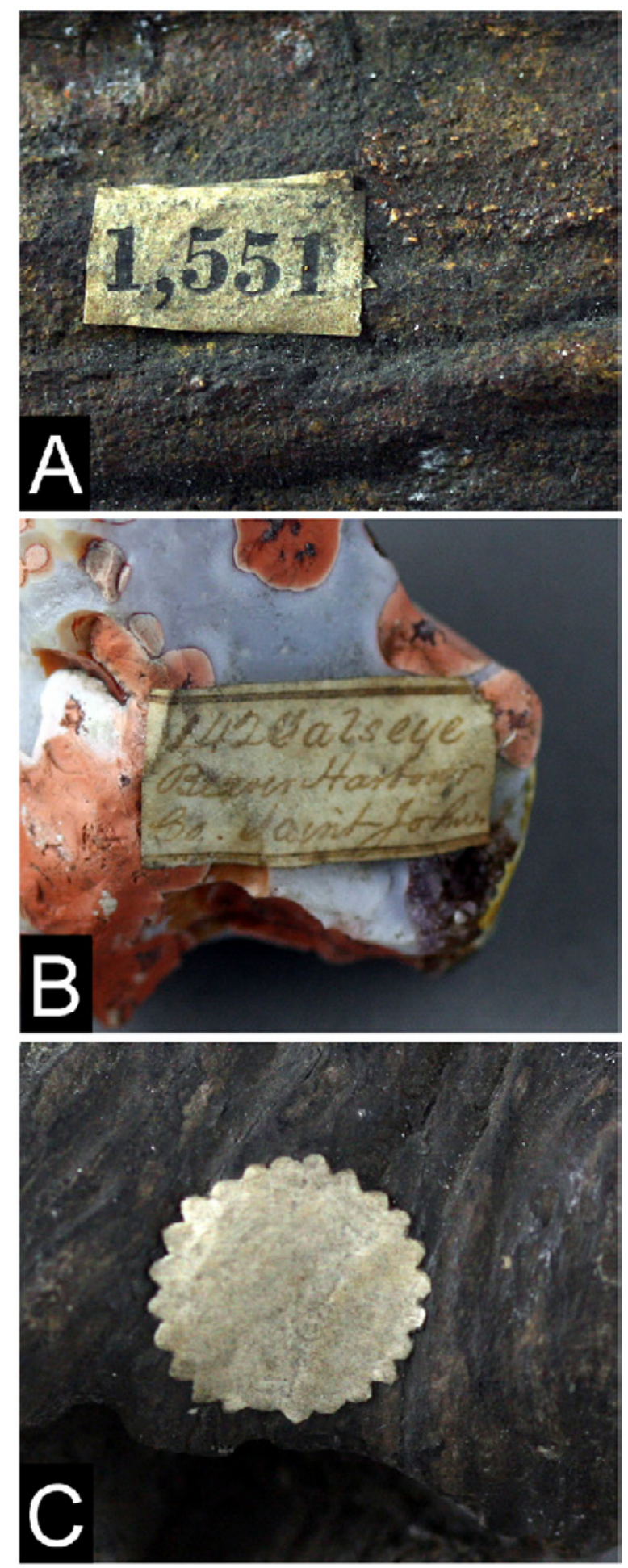

Fig. 5. Labels affixed to Gesner specimens in the New Brunswick Museum collection. (A) A "Gesner's Museum" label. Labels on specimens listed in the Appendix to Gesner's Museum are similar. (B) descriptive labels attached to selected specimens possibly by the Natural History Society of New Brunswick. (C) white "star-shaped" label found on variety of Gesner's specimens. twice the number of specimens identified in present collections. Missing specimens may have been re-labeled and are simply not recognized as originating with Gesner. Some may have been lost or sent elsewhere. In his reports, Gesner stated that "Specimens of all the useful minerals collected during the survey will be laid with this report before Your Excellency" (Gesner 1839, p. 9). No collections have been identified so far that correspond to specimens sent to the Lieutenant Governor by Gesner. "Gesner's Museum" also includes many specimens received from geologists in the United States and Europe (Miller and Buhay 2007). We can surmise that he might have traded some of his collection in return for material from elsewhere.

\section{SIGNIFICANCE OF THE GESNER SURVEY COLLECTION}

Many of the New Brunswick specimens that Gesner collected document rock formations he described, mineral occurrences noted in his reports, and significant fossil sites. For example, specimens like Gesner's barite sample (NBMM 1900) (Fig. 6F) from the Dipper Harbour area (Barr and White 2005) documents the discovery of the Little Dipper Harbour Barite occurrence recorded by the New Brunswick Geological Surveys Branch (2012) as Mineral Occurrence Number 0557. The Mineral Occurrence Database attributes the discovery to Abraham Gesner in 1839, and specimen NBMM 1900 indicates that discovery as part of Gesner's 1838 fieldwork.

Specimens of coral (NBMG 2867) (Fig. 6Q) listed in the "Appendix to the Catalogue of Gesner's Museum 1842-1843" (New Brunswick Museum Archives - Natural History Society Fonds S 128A, F 133) were collected during Gesner's visit to Dalhousie in 1842 (Gesner 1843) from the well-known Devonian marine fossil site in the Val d'Amour Formation. This was later described in detail by Clarke (1909).

Part of Gesner's fame rests with his discovery of a process to distill kerosene (Beaton 1955; Brice 2002) and his use of the bitumen albertite. Gesner is suspected to have recognized albertite in the field in about 1840 . His reports (Gesner 1840, p. 66-68; 1841, p. 27-28) show that he certainly described oil shale and bitumen from the "Westmorland Coal Field", where he found "on a new road and path connecting Hopewell and Hillsboro, a quantity of the material taken from the bottom of a small ravine" (Gesner 1840 , p. 66). This road probably passed through Albert Mines, suggesting that the small ravine could be Frederick Brook, the classic locality for albertite (Martin 2003). Until 1845, Westmorland County included the area that is now called Albert Mines and located in Albert County. Gesner had two specimens of Albert Formation oil shale 


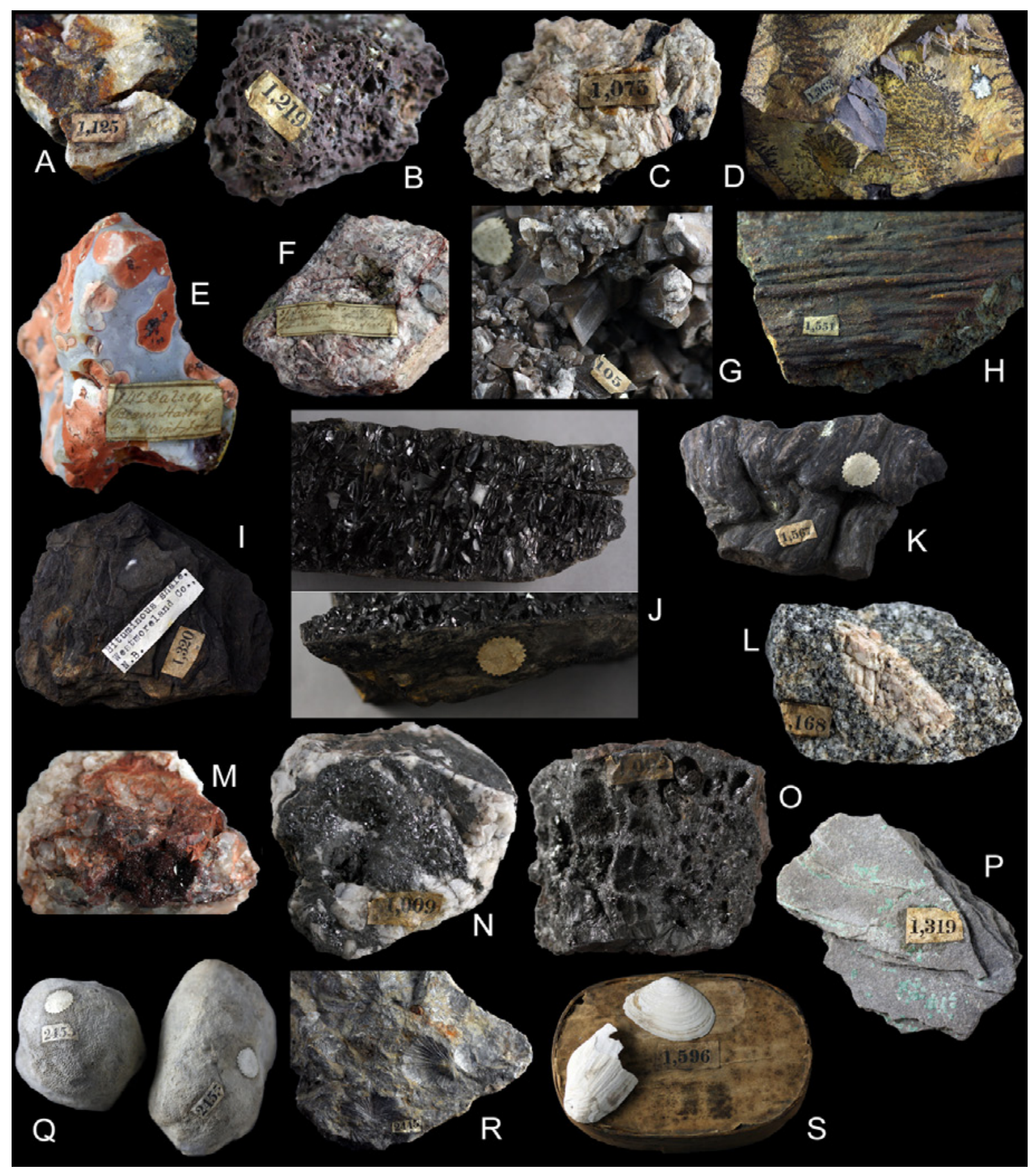

Fig 6. Selected New Brunswick specimens from Gesner's Geological Survey of New Brunswick, showing all three label styles found on Gesner's specimens. Information includes New Brunswick Museum catalogue number, identification, collection location, year of publication in Gesner's geological report and image width $(\mathrm{cm})$. (A) NBMM 3564 pyrite, Campobello Island, 1839, $6 \mathrm{~cm}$. (B) NBMR 1172 amygdaloid basalt, Grand Manan Island 1839, $6 \mathrm{~cm}$. (C) NBMM 2529 tourmaline, Waweig River 1839, $6 \mathrm{~cm}$. (D) NBMR 1270 manganese dendrites, Digdeguash River, 1839, $16 \mathrm{~cm}$. (E) NBMM 3172 quartz, Beaver Harbour, 1839, 4 cm. (F) NBMM 1900 barite, Dipper Harbour, 1839, 8 cm. (G) NBMM 2265 gypsum, Sussex Vale, 1840, $6 \mathrm{~cm}$. (H) NBMG 1104 unidentified plant fossil, Grindstone Island, 1840, $15 \mathrm{~cm}$. (I) NBMR 1260 bituminous shale, Albert Mines or Belliveau, 1840 or 1841, $10 \mathrm{~cm}$. (J) NBME 1130 albertite, Albert Mines(?), 1840 or 1841, $12 \mathrm{~cm}$. (K) NBMG 1109 unidentified plant fossil, Rockport (North Joggins), 1840, $12 \mathrm{~cm}$. (L) NBMR 1130 granite, Pokiok River, $1842,8 \mathrm{~cm}$. (M) NBMM 2531 barite, Miramichi, 1842, $8 \mathrm{~cm}$. (N) NBMM 2516 manganese quartz, Tetagouche River, $1843,6 \mathrm{~cm}$. (O) NBMM 2513 manganite, Bathurst, 1843, $7 \mathrm{~cm}$. (P) NBMR 1259 shale with copper, Bathurst, 1842 or $1843,8 \mathrm{~cm}$. (Q) NBMG 2867 Favosites coral, Dalhousie, 1843, $12 \mathrm{~cm}$. (R) NBMG 1579 unidentified brachiopods, River Charlo, $1843,11 \mathrm{~cm}$. (S) NBMG 1123 Hiatella and Macoma mollusks, Bathurst, 1843, $8 \mathrm{~cm}$ (box). 
Table 1. Examples of New Brunswick specimens from Abraham Gesner's collection indicating Gesner's identification and catalogue number, collection location, and Gesner's survey report page reference where specimens match the geological description. The New Brunswick Museum catalogue number, and New Brunswick Department of Natural Resources Mineral Occurrence numbers are indicated where appropriate.

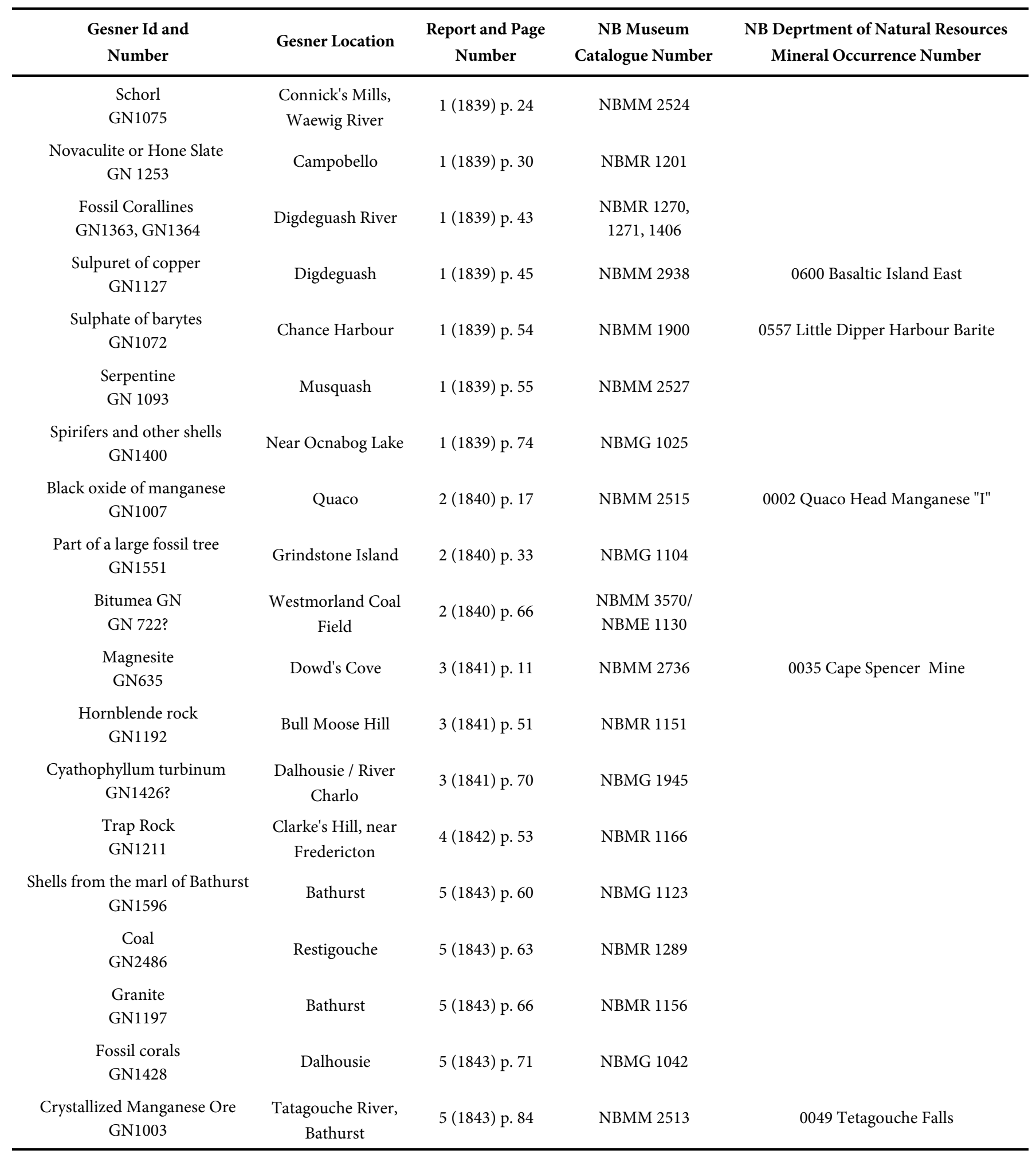


from Westmorland in his museum (Gesner 1842b), listed as "Gesner's Museum" numbers 678 (NBMR 1121) and 1,320 (NBMR 1260) (Fig. 6I). Albertite has not been identified in the "Gesner's Museum" collection by one of his standard "museum" labels (Fig. 5A), although "Gesner's Museum" number 722 , on page 20 of his catalogue (Gesner 1842b), is listed as "bitumea" from Westmorland. Re-evaluation of the New Brunswick Museum collection indicates that specimens bearing a specific white star-shaped label (Fig. 5C) are exclusive to Gesner's specimens. If so, NBMM 3570 and NBME 1130 (Fig. 6J) were Gesner's specimens of albertite and were collected in 1839 and/or 1840.

Abraham Gesner's geological collection, including specimens in "Gesner's Museum", represents one of the oldest geological collections in Canada. It has survived as an identifiable collection attributed to an individual, and probably traces its origin to the 1820s (Miller and Buhay 2007). The specimens from New Brunswick were collected as part of Gesner's Geological Survey of the province while he was employed as the first government-appointed Provincial Geologist in a British colony (Zeller 1987). Gesner's collection represents the second oldest government geological survey collection in the British Empire, following that of the British Geological Survey established in 1835. The current Geological Surveys Branch of the New Brunswick Department of Natural Resources is a direct descendant of the geological survey that began in April of 1838 .

\section{ACKNOWLEDGEMENTS}

The authors thank J. Longon, New Brunswick Museum Archives and Research Library for valuable help as always. R. Miller gratefully acknowledges the assistance of the Geological Surveys Branch of the New Brunswick Department of Natural Resources over the past 25 years. B. Brice and S. Donovan, and editor R. Fensome provided helpful comments to improve the manuscript. Transcriptions of newspaper articles and Abraham Gesner's letters to Sir John Harvey can be found on the New Brunswick Geological Surveys Branch Mineral History Database (http://www1.gnb.ca/0078/GeoscienceDatabase/ MineralHistory/MinHis-e.asp).

\section{REFERENCES}

Anonymous. 1838. Journal of the House of Assembly of the Province of New Brunswick from the twentieth eighth day of December to the ninth day of March. J. Simpson, Fredericton, N.B., 244 p., i-lviii p.

Anonymous. 1842. Journal of the House of Assembly of the Province of New Brunswick from the nineteenth day of
January to the fourth day of April. J. Simpson, Fredericton, N.B., 637 p., i-xlix p.

Barkhouse, J. 1980. Abraham Gesner. Fitzhenry and Whiteside, Don Mills, Ontario, 64 p.

Barr, S.M., and White, C.E. 2005. Bedrock geology of the Musquash area (NTS 21 G/01), Saint John, Charlotte, and Kings Counties, New Brunswick. New Brunswick Department of Natural Resources. Minerals, Policy and Planning Division. Plate 2005-26, scale 1:20 000.

Beaton, K. 1955. Dr. Gesner's kerosene: the start of American oil refining. Business History Review, 29, pp. 28-53. http://dx.doi.org/10.2307/3111597

Brice, W.R. 2002. Abraham Gesner (1797-1864) - a petroleum pioneer. Oil-Industry History, 3, pp. 72-80.

Calder, J.H. 2006. "Coal Age Galapagos": Joggins and the lions of nineteenth century geology. Atlantic Geology, 42, pp. 37-51.

Clarke, J.M. 1909. Early Devonic history of New York and eastern North America, part 2. New York State Museum, Memoir, 9, $250 \mathrm{p}$.

Cumming, L.M. 1988. Abraham Gesner. In Canadian Encyclopedia, Volume 2. Second Edition. Edited by J.H. Marsh. Hurtig Publishers Ltd., Edmonton, p 898.

Falcon-Lang, H.J. 2009. The 1835 Williams College expedition to Atlantic Canada: the first geological fieldtrip by a North American college. Atlantic Geology, 45, pp. 95-109.

Gesner, A. 1836. Remarks on the geology and mineralogy of Nova Scotia. Gossip and Coade, Halifax, 272 p.

Gesner, A. 1839. First report on the geological survey of the province of New Brunswick. Henry Chubb, Saint John, $87 \mathrm{p}$.

Gesner, A. 1840. Second report on the geological survey of the province of New Brunswick. Henry Chubb, Saint John, $76 \mathrm{p}$.

Gesner, A. 1841. Third report on the geological survey of the province of New Brunswick. Henry Chubb, Saint John, $88 \mathrm{p}$.

Gesner, A. 1842a. Fourth report on the geological survey of the province of New Brunswick. Henry Chubb, Saint John, $101 \mathrm{p}$.

Gesner, A. 1842b. Synopsis of the contents of Gesner's Museum of Natural History at Saint John, N.B. opened on the fifth day of April 1842. Henry Chubb, Saint John, 48 p.

Gesner, A. 1843. Report on the geological survey of the province of New Brunswick with a topographical account of the public lands, and the districts explored in 1842 . Henry Chubb, Saint John, 88 p.

Lyell, C. 1845. Travels in North America; with geological observations on the United States, Canada and Nova Scotia, volume 2. John Murray, London, $272 \mathrm{p}$.

Martin, G.L. 2003. Gesner's dream. The trials and triumphs of early mining in New Brunswick. Canadian Institute of Mining, Metallurgy and Petroleum - New Brunswick 
Branch. Fredericton, New Brunswick, 328 p.

Matthew, G.F. 1890. President's annual address. Natural History Society of New Brunswick, Bulletin, 9, pp. 25-35.

Matthew, G.F. 1897. Abraham Gesner. A review of his scientific work. Natural History Society of New Brunswick, Bulletin, 15, pp. 3-48.

Matthew, G.F. 1913. Sketch of the history of the Natural History Society of New Brunswick. Natural History Society of New Brunswick, Bulletin, 30, pp. 457-474.

Miller, R.F., and Buhay, D.N. 2007. Gesner's Museum of Natural History, an early Canadian geological collection. Geoscience Canada, 34, pp. 37-48.

New Brunswick Geological Surveys Branch 2012. Mineral Occurrence Database. New Brunswick Department of Natural Resources, Geological Surveys. URL <http:// dnre-mrne.gnb.ca/mineraloccurrence/> March 201
Russell, L.S. 1976. Gesner, Abraham. In Dictionary of Canadian biography, Vol. 9, 1861 to 1870 . Edited by G.W. Brown, D.M. Hayne, and F.G. Halpenny. University of Toronto Press, pp. 308-312.

Teather, L. 2005. The Royal Ontario Museum: a prehistory, 1830-1914. Canada University Press, 335 p.

Zaslow, M. 1975. Reading the Rocks. The story of the Geological Survey of Canada 1842-1972. MacMillan, London, $599 \mathrm{p}$.

Zeller, S. 1987. Inventing Canada: early Victorian science and the idea of a transcontinental nation. University of Toronto Press, Toronto, 356 p.

Editorial responsibility: Robert A. Fensome 